\title{
GÊNERO E AFRICANIDADE NA ARTE LATINO-AMERICANA CONTEMPORÂNEA
}

\author{
Amanda Marques Vieira, Janaína Silva Xavier e Letícia Sponton Cândido*
}

\section{Resumo}

O trabalho em questão tem por objetivo fazer uma interlocução entre história e arte no contexto da produção artística latino-americana contemporânea, mais especificamente na produção feminina e negra, abordando temas como, gênero, racismo, violência política e religiosidade. As principais fontes de análise são as produções de três artistas negras: a colombiana Dóris Salcedo (1958), a brasileira Rosana Paulino (1967) e a cubana Belkis Ayón (1967-1999). Com base nessa perspectiva pretende-se estabelecer um espaço de discussão, analisando os possíveis pontos de encontro e fuga levando em consideração a diversidade dos contextos históricos em que foram produzidas, os objetos utilizados e, até mesmo, suas percepções individuais.

\section{Palavras-chave: \\ História, Arte, Mulheres Negras.}

\section{Introdução}

Esse estudo tem por tema a arte de mulheres negras na América Latina e, mais especificamente, como objeto de análise, a produção de três artistas: a colombiana Dóris Salcedo (1958), a brasileira Rosana Paulino (1967) e a cubana Belkis Ayón (1967-1999), como fonte para discussão da história artística e cultural contemporânea, analisando os possíveis pontos de encontro e fuga levando em consideração a diversidade dos contextos históricos que foram produzidas e, até mesmo, suas percepções individuais. Sobre a América Latina, o crítico de arte Frederico de Morais (1997) e a curadora Aracy Amaral (2006) se equiparam no sentido de abordar que os estereótipos e preconceitos criados em torno dos latinos se devem a diversidade cultural das diversas regiões historicamente construídas como exóticas, assim como os problemas relacionados à política e a economia que são uma razão para o desprestígio da arte latina. Entretanto como aponta Morais (1997) os países latino-americanos são cada vez mais conscientes de sua autonomia criativa com temáticas encontradas em seus próprios países ou vivências. Outro desafio que se apresenta é a invisibilidade, os limites e reducionismos da produção artística da mulher latino-americana, especialmente de mulheres negras. Para Tvardovkas (2013) as obras dessas artistas latinas, não "levantam bandeiras", sua atuação está na criação de narrativas sobre o feminino desconstruindo estereótipos e nos ativismos políticos. Deste modo, para Simoni, et al (2013) é preciso realizar debates sobre arte, gênero, racismo, entre tantos outros temas que permeiam o cotidiano da América Latina. Diante disso, as narrativas das três artistas negras latinoamericanas, Dóris Salcedo, Rosana Paulino e Belkis Ayón, são significativas para discutir o respeito às diferenças e percursos particulares, buscando formular interpretações para suas obras que possam ajudar a discutir a história da arte feminina latino-americana e seus contextos.

\section{Resultados e Discussão}

Esta pesquisa parte da percepção da atuação de artistas negros no sistema das artes, principalmente a produção artística de mulheres que buscam em suas obras promover debates em relação às questões sociais. A artista colombiana Dóris Salcedo questiona em suas instalações a violência política esmaltada na memória das vítimas, utilizando materiais e objetos como símbolos da crueldade humana infringida no outro, que provoca um olhar crítico e reflexivo para sentir a privação do silêncio deixado no espaço, na qual a memória é o último prelúdio contra o esquecimento causado pelo extermínio da própria vida. Por sua vez, Rosana Paulino propõe indagar memórias das origens da sociedade brasileira tendo como análise a posição que a mulher negra tem no corpo social, representando elementos que denunciam ações discriminatórias que evidenciam experiências da escravidão permeadas na lembrança de um povo que teve que se refazer em uma cultura diferente da sua, apresentando um tom de denúncia às marcas relegadas da barbárie humana. Nesse contexto da representatividade da mulher negra no tecido social, a cubana Belkis Ayón procurou expressar as origens da comunidade fraterno-religiosa Abakuá, reivindicando a atuação da mulher dentro de uma sociedade patriarcal e machista expondo esse silêncio construído por costumes religiosos em seres que são desprovidos de boca/voz/palavra, a fim de aduzir o protagonismo do sexo feminino na comunidade.

\section{Conclusões}

Analisar as poéticas das três artistas negras latinoamericanas permite suscitar reflexões de outras vertentes da arte contemporânea sob novas perspectivas acerca da produção artística latina e, especialmente pelas indagações que as artistas promovem em relação ao contexto em que estão inseridas, mostrando problemáticas que se cruzam ou se afastam, resultando em obras que têm em si questionamentos.

\section{Agradecimentos}

Agradecemos ao UNASP-EC e ao Programa Residência Pedagógica/ CAPES pela ajuda e financiamento desta pesquisa.

AMARAL, A. A. Textos do Trópico de Capricórnio: artigos e ensaios (19802005) - Vol. 2: Circuitos de arte na América Latina e no Brasil. São Paulo: Editora 34, 2006.

MORAIS, F. Reescrevendo a história da arte latino-americana. In: MORAIS Frederico de (org.). Catálogo da I Bienal de Artes Visuais do Mercosul. Porto Alegre: Fundação Bienal de Artes Visuais do Mercosul, 1997. p.7-15. Catálogo de exposição.

SIMIONI, A. P. C.; DOROTINSKY, D.; DE LUCA, M.. Mulheres criadoras na América Latina: o desafio de sintetizar sem singularizar. Revista Artelogie n. 5, 2013.

TVARDOVSKAS, L. S. Tramas feministas na arte contemporânea brasileira e argentina: Rosana Paulino e Claudia Contreras. Revista Artelogie, n. 5, 2013. 